\title{
Grade of Atypia in Dysplastic Nevi and Relationship with Dermal Fibroplasia
}

\section{Displastik Nevüslerde Atipi Derecesinin Dermal Fibroplazi ile İlişkisi}

\author{
Ahmet BABACAN, Banu LEBE \\ Department of Pathology, Dokuz Eylül University, Faculty of Medicine, IZMIR, TURKEY
}

\begin{abstract}
Objective: Dysplastic nevus is described as an important factor in increasing the risk of melanoma. Many authors suggested dysplastic nevi should be graded according to architectural and cytological features. Dermal fibroplasia can be in concentric or lamellar fashion. In our study we aim to grade architectural and cytological atypia in dysplastic nevi and to assess the relationship between atypia and dermal fibroplasia.
\end{abstract}

Material and Method: Ninety-three biopsies obtained from 71 patients were included in the study group. Hematoxylin-eosin stained slides were evaluated and graded according to architectural and cytological features. A total score was obtained for both architectural and cytological atypia in each case. Masson Trichrome stained sections were used to assess dermal fibroplasia and evaluated semiquantitatively.

Results: Twenty-eight (30.1\%) cases had mild, 48 (51.6\%) cases moderate, and $17(18.3 \%)$ cases had severe atypia regarding architectural features. Nine (9.7\%) cases were scored having mild, 28 (30.1\%) cases moderate, and $56(60.2 \%)$ cases having severe atypia regarding cytologic features. There was a significant correlation between the degree of architectural and cytologic atypia. Six (21.4\%) cases with mild, $31(64.6 \%)$ cases with moderate, and 12 cases (70.6\%) with severe architectural atypia had dermal fibroplasia. One case $(11.1 \%)$ with mild, 10 cases (\% 35.7) with moderate, and 10 cases (67.9\%) with severe cytological atypia had dermal fibroplasia. A significant relationship was found between the presence of fibroplasia and the degree of cytological and architectural atypia.

Conclusion: A statistically significant relationship was revealed between the increase of architectural and cytological atypia and dermal fibroplasia. Detection and evaluation of stromal changes by histochemical methods, and scoring of atypia in dysplastic nevi may be helpful to distinguish dysplastic from other banal nevi.

Key Words: Dysplastic nevus, Atypia, Dermal fibroplasia

\section{INTRODUCTION}

Ever since the histological definition of dysplastic nevus (DN) by Clark et al., discussions have focused on

Received : 22.04.2011

Accepted : 05.09.2011

\section{ÖZ}

Amaç: Displastik nevüs melanom riskini artıran önemli bir faktör olarak tanımlanmaktadır. Çoğu araștırıcı displastik nevüsleri yapısal ve sitolojik özelliklerine göre derecelendirmeyi önermektedir. Dermal fibroplazi konsantrik ve lamellar şekilde olabilmektedir. $\mathrm{Bu}$ çalışmanın amacı, displastik nevüslerde yapısal ve sitolojik atipi derecesinin belirlemek ve bu atipinin dermal fibroplazi ile ilişkisini araştırmaktır.

Gereç ve Yöntem: Yetmiş bir hastaya ait 93 lezyon çalışmanın gerecidir. Hematoksilen-eozin boyalı kesitler incelenerek, yapısal ve sitolojik atipi derecelendirildi. Yapısal ve sitolojik atipinin toplam skoru her olgu için elde edildi. Dermal fibroplazi değerlendirilmesi için Masson Trikrom boyası uyguland $\_$ve semikantitatif olarak değerlendirildi.

Bulgular: Yirmi sekiz olguda (\%30.1) hafif, 48 olguda (\%51.6) orta ve 17 olguda (\%18.3) şiddetli derecede yapısal atipi saptand. Dokuz olguda (\%9.7) hafif, 28 olguda (\%30.1) orta ve 56 olguda (\%60.2) şiddetli derecede sitolojik atipi gözlendi. Yapısal ve sitolojik atipi dereceleri arasında anlamlı korelasyon saptandı. Hafif yapısal atipili 6 olguda (\%21.4), orta derecede yapisal atipili 31 olguda (\%64.6), şiddetli derecede yapısal atipili 12 olguda (\%70.6), hafif sitolojik atipili 1 olguda (\%11.1), orta derecede sitolojik atipili 10 olguda (\%35.7) ve şiddetli derecede sitolojik atipili 10 olguda (\%67.9) dermal fibroplazi saptandi. Sitolojik ve yapısal atipi dereceleri ile dermal fibroplazi varlığı arasında anlamlı ilişki bulundu.

Sonuç: Çalışmamızda displastik nevüslerde yapısal ve sitolojik atipi derecesi arttıkça dermal fibroplazide anlamlı artış saptandı. Displastik nevüslerdeki atipinin derecelendirilmesi ve stromal değișikliklerin histokimyasal yöntemlerle saptanması, displastik nevüsların diğer banal nevüslerden ayrımında yardımcı olabilir.

Anahtar Sözcükler: Displastik nevüs, Atipi, Dermal fibroplazi

the relationship between the histological changes and malignant melanoma (MM) risk and familial MM (1). Familial DN syndrome is the presence of multiple nevi

Correspondence: Banu LEBE

Department of Pathology, Dokuz Eylül University, Faculty of Medicine, İZMİR, TURKEY

E-mail: banu.lebe@deu.edu.tr Phone: +90 2324123412 
together with a familial or personal MM history. Sporadic DN syndrome is the presence of a varying number of nevi without any familial history $(2,3)$. The melanocytic nevi seen with DN syndrome histologically show melanocytic dysplasia and their microscopic appearance is said to be associated with a markedly increased neoplastic risk (2). Clark et al. have considered architectural and cytological atypia together in the diagnosis of melanocytic dysplasia (4). Major and minor criteria have been defined for DN diagnosis. Papillary dermal fibroplasia, one of the minor criteria, is in the form concentric eosinophilic fibroplasia or lamellar fibroplasia $(5,6)$.

Many recent epidemiological $(1,7,8)$, morphological (1, 7-10), immunohistochemical (11-14) and genetic (15-20) studies support the notion that $\mathrm{DN}$ is a major risk factor for melanoma even if not a direct precursor.

Many studies support atypia grading for DN but there is marked variability both for intra-observer and interobserver values (21-24). Neoplastic stromal changes progress together with the characteristic parenchymal changes in melanocytic tumor progression (6). A band-like lymphocytic infiltrate together with diffuse fibroplasia is seen more commonly in MM (25). There are many opinions on the development mechanism for the dermal fibroplasia during the MM tumorigenesis $(6,25)$ but there is no study on the relationship between architectural and cytological atypia grading in DN's and dermal fibroplasia. The aim of this study was to evaluate atypia according to architectural and cytological features of $\mathrm{DN}$ and to demonstrate the potential relationship of this atypia with dermal fibroplasia.

\section{MATERIAL and METHODS}

A total of 93 lesions from 71 patients diagnosed as DN between the years 2003 and 2008 at Dokuz Eylul University Department of Pathology were included in this study. The patient's personal history, age, gender, and the anatomical localization of the lesion were found from the files and recorded. The $4 \mu \mathrm{m}$ thick Hematoxylin \& Eosin (H\&E) stained sections that had been prepared from formalinfixed and paraffin embedded tissues were re-evaluated by two pathologists ( $\mathrm{AB}$ and $\mathrm{BL}$ ) and $\mathrm{DN}$ diagnoses were confirmed. The atypia of the cases included in the study were scored and graded according to Shea et al. (26). Table I summarizes the architectural and cytological atypia.

The architectural features, circumscription, symmetry, cohesion, suprabasal melanocytes, confluence, and single cell proliferation were scored and evaluated. The total of obtained scores gave the degree of architectural atypia. $0-1=$ Mild architectural atypia (MiAA), 2-3 = Moderate architectural atypia (MoAA), 4-6 = Severe architectural atypia (SAA). The cytological features were evaluated by scoring the nuclear shape and staining, nuclear size, nucleolar prominence and melanocyte cell size.
The total of obtained scores gave the degree of cytological atypia as 0-1: Mild cytological atypia (MiCA), 2: Moderate cytological atypia (MoCA) 3-4: Severe cytological atypia (SCA). Masson's Trichrome histochemical technique was used to show dermal fibroplasia in DN (27). The sections stained with Masson's Trichrome stain were evaluated under light microscopy by 2 pathologists and were scored semiquantitatively as fibroplasia present (1) or absent (0).

The architectural and cytological grades and histochemical staining characteristics of the cases were evaluated with statistical analysis. The association between the degree of atypia in the DN and the Masson Trichrome staining scores was investigated. Data were analyzed using Scientific Package for Social Sciences Software (SPSS) and Epi Info 2002 Statcalc programs. Pearson Chi square, Chi square test for trend and Spearman correlation tests were used. A $p$ value less than 0.05 was accepted as significant.

\section{RESULTS}

The age range of the 71 cases included in the study at the time of diagnosis were 12 to 75 years with median value of 33.62. The cases were distributed as 32 females and 39 males. There were $93 \mathrm{DN}$ lesions from 71 patients. The DN lesions were distributed as 33 (35.5\%) junctional and 60 (64.5\%) compound lesions.

Table II shows the distribution of the cases by anatomic localization.

The most common architectural disorders were confluence in the junctional melanocytes (Figure 1), the loss of termination with a nest in one or both ends and the presence of single cell melanocytic proliferation.

The architectural atypia features of the cases have been summarized in Table III. We found MiAA in 28 cases $(30.1 \%)$, MoAA in 48 cases $(51.6 \%)$ and SAA in 17 cases (18.3\%).

The most common cytological features were abnormal nuclear shape and staining pattern (Figure 2), large cell diameter, nucleolar prominence and marked nuclear enlargement. Table IV summarizes the cytological atypia features and scores. We found MiCA in 9 cases $(9.7 \%)$, MoCA in 28 cases (30.1\%) and SCA in 56 cases (60.2\%).

A total of $6 \mathrm{MiAA}$ cases (21.4\%), $31 \mathrm{MoAA}$ cases (64.6\%), and 12 SSA cases (70.6\%) showed marked dermal fibroplasia with Masson Trichrome histochemistry (Figure 3) (Table V).

Marked dermal fibroplasia on Masson Trichrome histochemistry was also found in $1 \mathrm{MiCA}$ case $(11.1 \%), 10$ MoCA cases (35.7\%) and 10 SCA cases (67.9\%) (Figure 4) (Table VI) .

The presence of dermal fibroplasia changed with the degree of architectural atypia $(\mathrm{p}<0.001, \mathrm{r}=0.354)$. The increased 
incidence of fibrosis with increasing architectural atypia degree $\left(\chi^{2}=15.88, p<0.0001\right)$ was found to be statistically significant.
The presence of dermal fibroplasia changes with the degree of cytological atypia $(\mathrm{p}<0.001, \mathrm{r}=0.371)$. We found the increasing incidence of fibrosis with increasing degree of

Table I: Architectural and cytological atypia grading criteria

\begin{tabular}{|l|c|c|}
\hline Architectural atypia & Score 0 & Score 1 \\
\hline Junctional component nest at both ends & yes & no \\
\hline Symmetry & yes & no \\
\hline Nest cohesion more than $50 \%$ & yes & yes \\
\hline Confluence more than $50 \%$ & no & no \\
\hline Single cell proliferation absent or focal & yes & Score 1 \\
\hline & Score 0 & no \\
\hline Cytological atypia & yes & yes \\
\hline Nucleus round, oval, euchromatic & no & yes \\
\hline Nucleus size $>$ basal keratinocyte nucleus & no & yes \\
\hline Nucleolar prominence & no & \\
\hline Cell diameter $>2 x$ basal keratinocyte nucleus diameter & & \\
\hline
\end{tabular}

Table II: Distribution of the cases by anatomical localization

\begin{tabular}{|l|c|c|}
\hline Anatomical localization & Number of cases (n) & Case percentage (\%) \\
\hline Trunk & 66 & 71.0 \\
\hline Arm & 7 & 7.5 \\
\hline Leg & 11 & 11.8 \\
\hline Unspecified & 9 & 9.7 \\
\hline Total & 93 & 100 \\
\hline
\end{tabular}

Table III: Architectural atypia features and scores of the cases

\begin{tabular}{|l|c|c|c|c|}
\hline \multirow{2}{*}{} & \multicolumn{2}{|c|}{ Score=0 } & \multicolumn{2}{c|}{ Score=1 } \\
\cline { 2 - 5 } & $\mathbf{n}$ & $\mathbf{\%}$ & $\mathbf{n}$ & $\mathbf{\%}$ \\
\hline Circumscription & 51 & 54.8 & 42 & 45.2 \\
\hline Symmetry & 68 & 73.1 & 25 & 26.9 \\
\hline Cohesion & 62 & 66.7 & 31 & 33.3 \\
\hline Suprabasal melanocytes & 72 & 77.4 & 21 & 22.6 \\
\hline Confluence & 44 & 47.3 & 49 & 52.7 \\
\hline Single cell proliferation & 58 & 62.4 & 35 & 37.6 \\
\hline
\end{tabular}

Table IV: Cytological atypia features and scores of the cases

\begin{tabular}{|l|c|c|c|c|}
\hline \multirow{2}{*}{} & \multicolumn{2}{|c|}{ Score=0 } & \multicolumn{2}{c|}{ Score=1 } \\
\cline { 2 - 5 } & $\mathbf{n}$ & $\mathbf{\%}$ & $\mathbf{0}$ \\
\hline $\begin{array}{l}\text { Abnormal nuclear shape and } \\
\text { staining }\end{array}$ & 39 & 41.9 & 54 & 58.1 \\
\hline Nuclear size & 34 & 36.6 & 59 & 63.4 \\
\hline Nucleolar prominence & 31 & 33.3 & 62 & 66.7 \\
\hline Cell size & 14 & 15.1 & 79 & 84.9 \\
\hline
\end{tabular}


Table V: Association between the degree of architectural atypia and dermal fibroplasia

\begin{tabular}{|l|c|c|c|c|}
\hline \multirow{2}{*}{ Degree of architectural atypia } & \multicolumn{2}{|c|}{ Dermal fibroplasia } & \multirow{2}{*}{ Total } \\
\cline { 2 - 5 } & $\mathrm{n}$ & 22 & 6 & 28 \\
\hline \multirow{2}{*}{ MiAA } & $\%$ & 78.6 & 21.4 & 100.0 \\
\cline { 2 - 5 } & $\mathrm{n}$ & 17 & 31 & 48 \\
\hline \multirow{2}{*}{ MoAA } & $\%$ & 35.4 & 64.6 & 100.0 \\
\hline \multirow{2}{*}{ SAA } & $\mathrm{n}$ & 5 & 12 & 17 \\
\cline { 2 - 5 } & $\%$ & 29.4 & 70.6 & 93 \\
\hline \multirow{2}{*}{ TOTAL } & 44 & 49 & 100.0 \\
\cline { 2 - 5 } & & 47.3 & 52.7 & \\
\hline
\end{tabular}

Table VI: Association between the cytological atypia grades and dermal fibroplasia

\begin{tabular}{|l|c|c|c|c|}
\hline \multirow{2}{*}{ Degree of cytological atypia } & \multicolumn{2}{|c|}{ Dermal fibroplasia } & \multirow{2}{*}{ Total } \\
\cline { 2 - 5 } & $\mathrm{n}$ & 8 & 1 & 9 \\
\hline \multirow{3}{*}{ MiCA } & $\%$ & 88.90 & 11.10 & 100.0 \\
\cline { 2 - 5 } MoCA & $\mathrm{n}$ & 18 & 10 & 28 \\
\cline { 2 - 5 } & $\%$ & 64.30 & 35.70 & 100.0 \\
\hline \multirow{2}{*}{ SCA } & $\mathrm{n}$ & 18 & 38 & 56 \\
\cline { 2 - 5 } & $\%$ & 32.10 & 67.90 & 100.0 \\
\hline \multirow{2}{*}{ TOTAL } & 44 & 49 & 93 \\
\cline { 2 - 5 } & & 47.3 & 52.7 & 100.0 \\
\hline
\end{tabular}

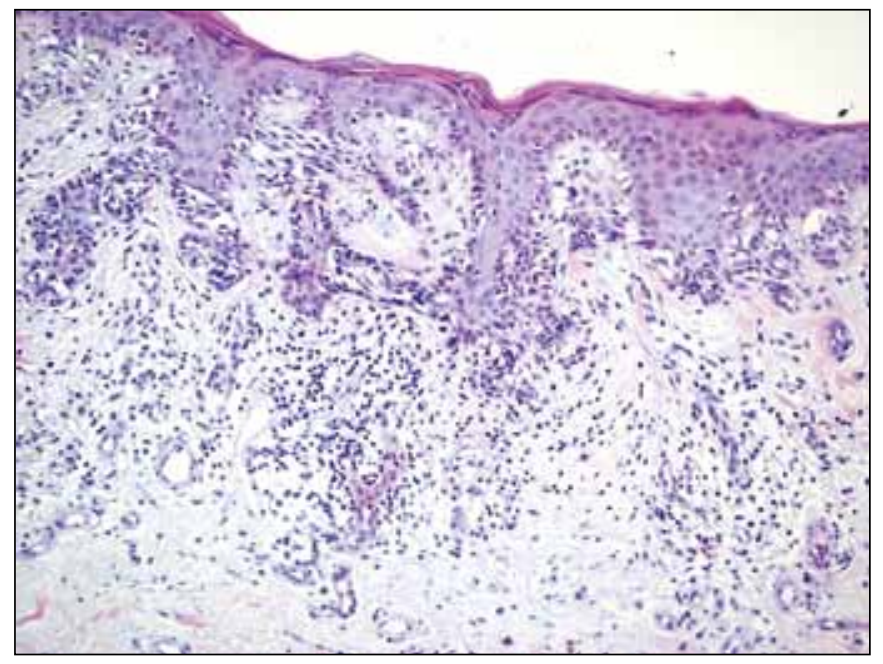

Figure 1: Confluence of the junctional melanocytes in dysplastic nevus (Hematoxylin eosin, x200).

cytological atypia to be statistically significant $\left(\chi^{2}=14.64\right.$, $\mathrm{p}<0.001)$.

The degree of architectural atypia changed with the degree of cytological atypia $(\mathrm{p}=0.05)$.

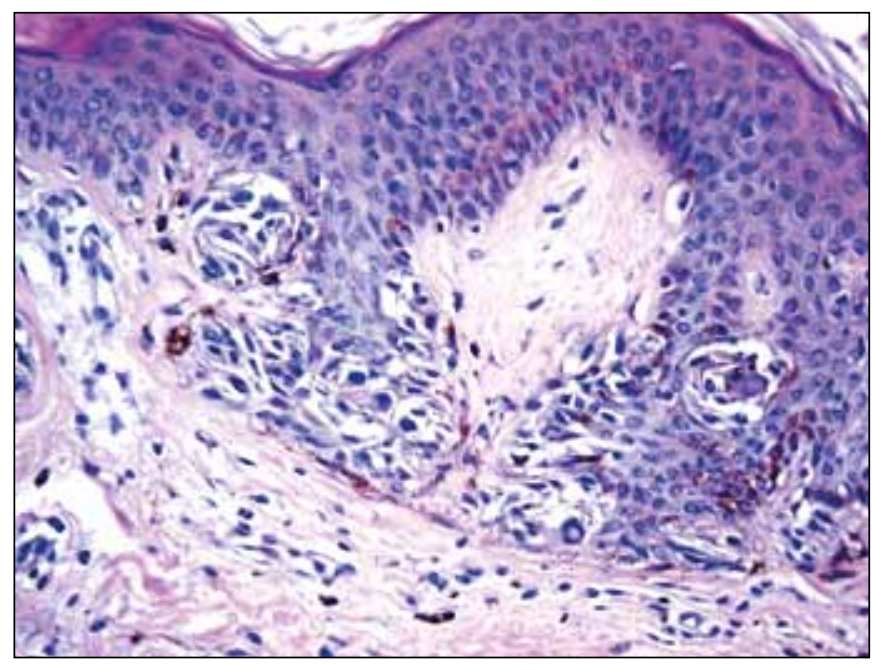

Figure 2: Abnormal nuclear shape and nuclear pattern in the melanocytic cell in dysplastic nevus (Hematoxylin eosin, $x 400$ ).

The presence of single cell proliferation that is the architectural atypia grading parameter changed with the presence of hyperchromatic or irregular shape nuclei that are features of cytologic atypia $(\mathrm{p}=0.013, \mathrm{r}=0.233)$. Similarly, the termination of the junctional component with a nest 


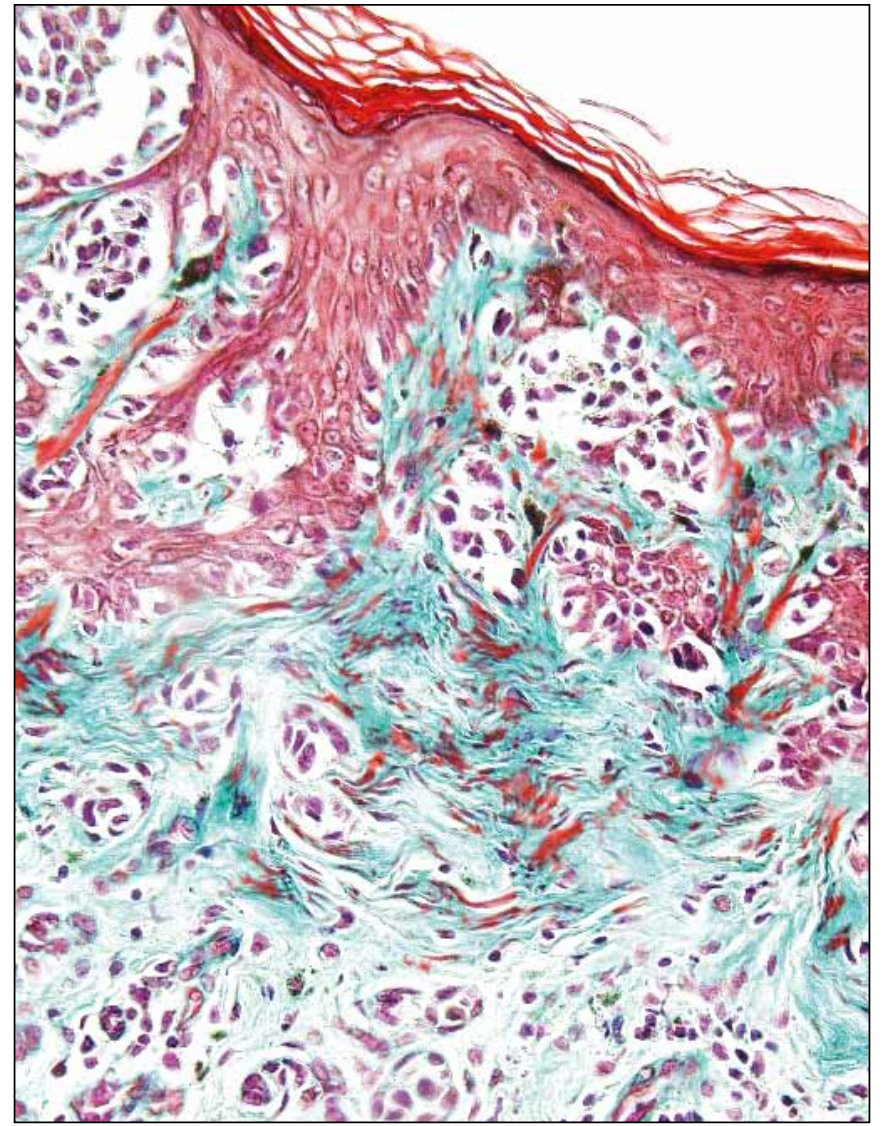

Figure 3: Dermal fibroplasia in a dysplastic nevus with severe architectural atypia (Masson's Trichrome stain, x200).

at both ends, that is a parameter of architectural atypia, changed significantly with the presence of a hyperchromatic or irregular shaped nuclei, that are cytological atypia parameters $(\mathrm{p}=0.005, \mathrm{r}=0.154)$.

Nucleolar prominence changed with discohesion of nests $(\mathrm{p}=0.013, \mathrm{r}=0.202)$ and single cell proliferation $(\mathrm{p}=0.000$, $\mathrm{r}=-0.449)$.

A cell diameter over twice the basal keratinocyte nucleus diameter changed significantly with more than 50\% bridge formation between junctional melanocytic nests or the presence of continuous single melanocytic cellular proliferation ( $\mathrm{p}=0.011, \mathrm{r}=0.230)$.

We also found a significant relationship between nucleolar prominence and the lack of termination of the junctional component with a nest at both ends $(\mathrm{p}=0.008, \mathrm{r}=0.153)$.

\section{DISCUSSION}

$\mathrm{DN}$ is an important risk factor and potential precursor for MM. Clark et al. were the first to show transformation to $\mathrm{MM}$ in two cases with a family history of $\mathrm{MM}$ and they named this condition the "B-K mole syndrome" (1). The lifelong risk of $\mathrm{MM}$ development in cases with the familial

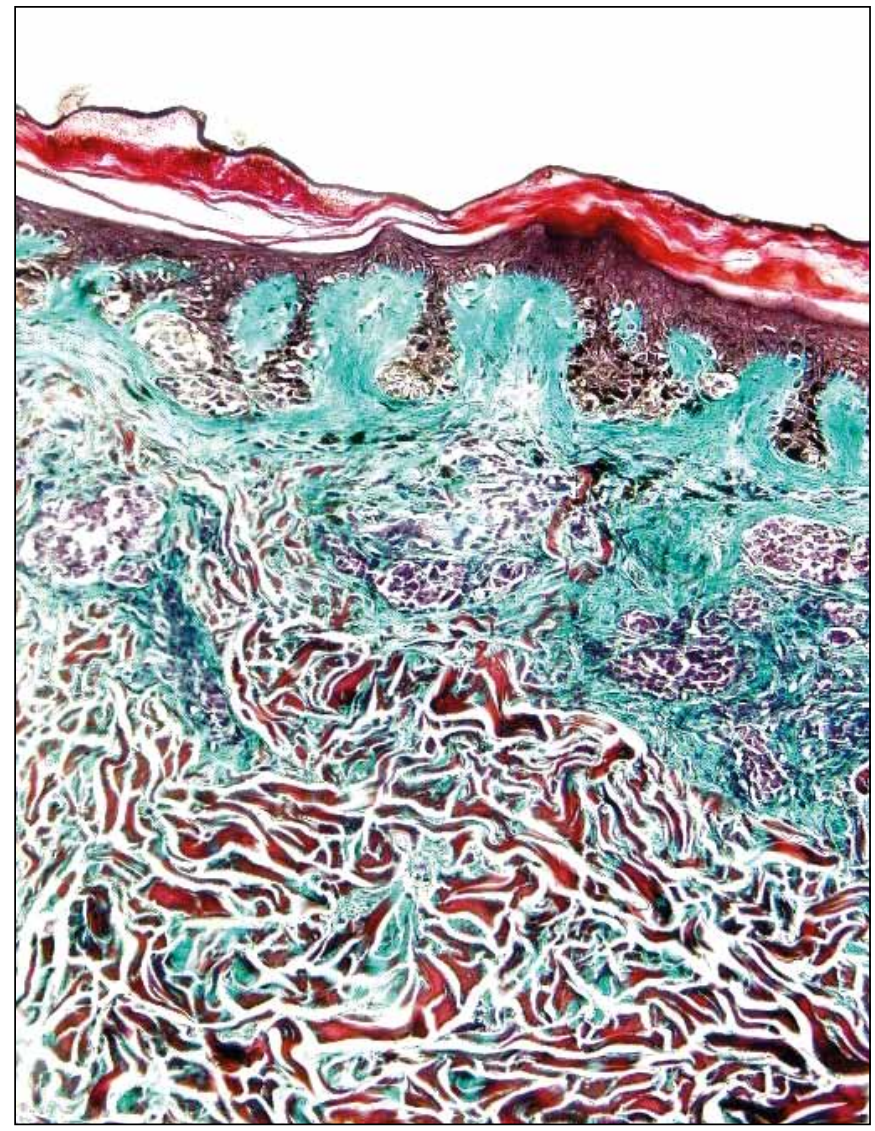

Figure 4: Dermal fibroplasia in a dysplastic nevus with severe cytological atypia (Masson's Trichrome stain, x100).

DN syndrome is almost $100 \%$ while this risk is 2 to 8 times higher than the general population in the sporadic DN syndrome (5). Many investigators recommend grading melanocytic atypia but the study results show a high degree of variability $(21-26,28-32)$. As far as we know, there is also no study on the possible relationship between these atypia degree and fibroplasia in the English literature.

Pozo et al. (24) have graded DN cases as low, moderate or high degree of dysplasia. We found severe dysplasia in $99.5 \%$ of DN cases using this criteria. However, we were unable to define significant architectural features that differentiated between a low and moderate degree of dysplasia. All the cases in the series had both architectural and cytological atypia. This study did not find a significant relationship between the nuclear pleomorphism and chromatin pattern and the severe atypia degree, in contrast to our findings. We separately scored the architectural and cytological features in DN cases and graded the atypia. We also evaluated the dermal fibroplasia. We found a significant relationship between both architectural and cytological atypia and dermal fibroplasia by comparing the architectural and cytological atypia degree and dermal fibroplasia. As the severity of architectural and cytological atypia increased, 
we observed that the fibroplasia rate also increased. We suggest that as different architectural disorders and cellular changes may be seen in the same case, the architectural and cytological atypia grading should be performed separately and these atypia grades should be interpreted together.

The scoring and grading of the degree of atypia of our cases was performed according to the criteria defined by Shea et al. (26). We found a significant association and correlation between the architectural and cytological degrees of atypia in this study. Although there are many studies on grading in the literature, there is no consensus on the descriptive criteria that constitute the basis of the grading. Some of the studies degree melanocytic dysplasia by only cytological characteristics (29) while others grade by both architectural and cytological characteristics (23, 26). Our findings show a significant relationship between architectural and cytological atypia similar to many studies in the literature. A larger number of studies with a larger number of cases are required for the standardization of grading and establishment of reliable criteria. Although we found a significant relationship between the degrees of architectural and cytological atypia in our study, we also had cases with different architectural and cytoogical atypia degrees. Although investigators report an increase in the incidence of a history of melanoma with increasing degree of dysplasia, it is possible that high grade melanocytic dysplasia cases without fibroplasia are present (23). Our results support the idea that an increasing grade of melanocytic dysplasia leads to a significant increase in the presence of dermal fibroplasia.

When grading this cytological atypia, we used the term "severe cytological atypia" in the presence of three or more nuclear criteria. We observed that dermal fibroplasia changed with the degree of cytological atypia. This finding may indicate that dermal fibroplasia may provide an additional criteria when interpreting the degree of cytological atypia in DN cases.

The dermal fibroplasia in DN can be concentric or lamellar fashion $(22,25,33,34)$. Concentric eosinophilic fibroplasia is generally associated with melanocytic atypia or aytpical lentiginous epidermal or melanocytic hyperplasia and is most commonly seen in precursor nevi. Lamellar fibroplasia is the most prominent stromal pattern. It can also be seen with invasive melanomas (6). It strongly indicates parenchymal extracellular matrix and tumor interaction. Lamellar fibroplasia indicates the end point of the progression of melanocytic precursor lesions. These changes are seen in a marked manner in lesions that are between DN and early melanoma (7). Light microscopy studies have shown that the nests and melanoma nests consisting of nevus cells are surrounded by basal membrane material consisting of type-IV collagen and laminin. The basal membrane material is of varying width and has an amorphous appearance. Type-IV collagen, laminin and MMP-2 are synthesized both by melanoma cells and the neighboring fibroblasts. It is not known whether basal membrane production is mostly from melanocytic cells or fibroblasts. The interaction between basal membrane melanocytes and ECM possibly develops as a result of the backwards migration of neural crest-derived melanocytes (35). This view partially explains the dermal fibroplasia found in $\mathrm{DN}$ cases.

The fibroplasia is thought to develop from the interaction of some growth factors secreted by proliferated melanocytes, adjacent keratinocytes and fibroblasts with autocrine or paracrine effect (36). Various stromal patterns have been defined in melanocytic dysplasia development $(6,37)$. We had no case of fibroplasia without cytological atypia in our study. The significantly increased rate of dermal fibroplasia with increasing cytological and architectural atypia supports these views. We found dermal fibroplasia together with nuclear atypia in 49 cases $(52.7 \%)$. However, we did not find dermal fibroplasia despite the presence of nuclear atypia in 44 cases (47.3\%). These findings indicate that the degree of stromal changes in DN can help in differentiating $\mathrm{DN}$ cases from other basal nevi.

Dermal fibroplasia is a valuable marker that reflects the neoplastic cell-stroma relationship in DN cases. Evaluation of dermal fibroplasia and determining its relationship with the degree of atypia in DN cases will contribute to new studies directed towards understanding the progression risk of DN to malignant melanoma.

\section{ACKNOWLEDGEMENT}

We would like to thank Prof. Uğur Pabuççuoğlu, M.D., for his valuable help in writing the article.

\section{REFERENCES}

1. Clark WH Jr, Reimer RR, Greene M, Ainsworth AM, Mastrangelo MJ: Origin of familial malignant melanomas from heritable melanocytic lesions. "The B-K mole syndrome". Arch Dermatol 1978, 114: 732-738

2. Elder DE, Goldman LI, Goldman SC, Greene MH, Clark WH Jr: Dysplastic nevus syndrome: a phenotypic association ofsporadic cutaneous melanoma. Cancer 1980, 46:1787-1794

3. Elder DE, Greene MH, Bondi EE, Clark WH Jr: Acquired Melanocytic Nevi and Melanoma. The Dysplastic Nevus Syndrome. In: Ackerman AB. (ed) Pathology of Malignant Melanoma. New York, Masson, 1981, 185-215

4. Seywright MM, Doherty VR, MacKie RM: Proposed alternative terminology and subclassification of so called "dysplastic naevi". J Clin Pathol 1986, 39: 189-194

5. Clemente C, Cochran AJ, Elder DE, Levene A, MacKie RM, Mihm MC, Rilke F, Cascinelli N, Fitzpatrick TB, Sober AJ: Histopathologic diagnosis of dysplastic nevi: concordance among pathologists convened by the World Health Organization Melanoma Programme. Hum Pathol 1991, 22: 313-319 
6. Clark WH Jr, Tucker MA, Goldstein AM: Parenchymal-stromal interactions in neoplasia. Theoretical considerations and observations in melanocytic neoplasia. Acta Oncol 1995, 34: 749-757

7. Clark WH Jr. Tucker MA: Problems with lesions related to the development of malignant melanoma: common nevi, dysplastic nevi, malignant melanoma insitu, and radial growth phase malignant melanoma. Hum Pathol 1998, 29: 8-14

8. Rhodes AR, Mihm MC Jr, Weinstock MA: Dysplastic melanocytic nevi: a reproducible histologic definition emphasizing cellular morphology. Mod Pathol 1989, 2: 306-319

9. Rhodes AR, Melski JW, Sober AJ, Harrist TJ, Mihm MC Jr, Fitzpatrick TB: Increased intraepidermal melanocyte frequency and size in dysplastic melanocytic nevi and cutaneous melanoma. A comparative quantitative study of dysplastic melanocytic nevi, superficial spreading melanoma, nevocellular nevi, and solar lentigines. J Invest Dermatol 1983, 80: 452-459

10. Langer K, Rappersberger K, Steiner A, Konrad K, Wolff K: The ultrastructure of dysplastic naevi: comparison with superficial spreading melanoma and common naevocellular naevi. Arch Dermatol Res 1990, 282: 353-362

11. Hussein MR, Roggero E, Sudilovsky EC, Tuthill RJ, Wood GS, Sudilovsky O: Alterations of mismatch repair protein expression in benign melanocytic nevi, melanocytic dysplastic nevi, and cutaneous malignant melanomas. Am J Dermatopathol 2001, 23 : 308-314

12. Lassam NJ, From L, Kahn HJ: Overexpression of p53 is a late event in the development of malignant melanoma. Cancer Res 1993, 53: 2235-2238

13. Smoller BR, McNutt NS, Hsu A: HMB-45 staining of dysplastic nevi. Support for a spectrum of progression toward melanoma. Am J Surg Pathol 1989, 13: 680-684

14. Takahashi H, Strutton GM, Parsons PG: Determination of proliferating fractions in malignant melanomas by anti-PCNA/ cyclin monoclonal antibody. Histopathology 1991, 18: 221-227

15. Hussein MR, Sun M, Tuthill RJ, Roggero E, Monti JA, Sudilovsky EC, Wood GS, Sudilovsky O: Comprehensive analysis of 112 melanocytic skin lesions demonstrates microsatellite instability in melanomas and dysplastic nevi, but not in benign nevi. J Cutan Pathol 2001, 28: 343-350

16. Birindelli S, Tragni G, Bartoli C, Ranzani GN, Rilke F, Pierotti MA, Pilotti S: Detection of microsatellite alterations in the spectrum of melanocytic nevi in patients with or without individual or family history of melanoma. Int J Cancer 2000, 86: 255-261

17. Park WS, Vortmeyer AO, Pack S, Duray PH, Böni R, Guerami AA, Emmert-Buck MR, Liotta LA, Zhuang Z: Allelic deletion at chromosome 9p21 (p16) and 17p13 (p53) in microdissected sporadic dysplastic nevus. Hum Pathol 1998, 29: 127-130

18. Böni R, Zhuang Z, Albuquerque A, Vortmeyer A, Duray P: Loss of heterozygosity detected on $1 \mathrm{p}$ and $9 \mathrm{q}$ in microdissected atypical nevi. Arch Dermatol 1998, 134: 882-883

19. Lee JY, Dong SM, Shin MS, Kim SY, Lee SH, Kang SJ, Lee JD, Kim CS, Kim SH, Yoo NJ: Genetic alterations of p16INK4a and p53 genes in sporadic dysplastic nevus. Biochem Biophys Res Commun 1997, 237: 667-672

20. Beitner H, Nakatani T, Hedblad MA: A transmission electron microscopical study of dysplastic naevi. Acta Derm Venereol 1990, 70: 411-416
21. de Wit PE, van't Hof-Grootenboer B, Ruiter DJ, Bondi R, Bröcker EB, Cesarini JP, Hastrup N, Hou-Jensen K, MacKie RM, Scheffer E: Validity of the histopathological criteria used for diagnosing dysplastic naevi. An interobserver study by the pathology subgroup of the EORTC Malignant Melanoma Cooperative Group. Eur J Cancer 1993, 29: 831-839

22. Murphy GF, Mihm MCJ: Recognition and evaluation of cytological dysplasia in acquired melanocytic nevi. Hum Pathol 1999, 30: 506-512

23. Arumi-Uria M, McNutt NS, Finnerty B: Grading of atypia in nevi: correlation with melanoma risk. Mod Pathol 2003, 16: 764-771

24. Pozo L, Naase M, Cerio R, Blanes A, Diaz-Cano SJ: Critical analysis of histologic criteria for grading atypical (dysplastic) melanocytic nevi. Am J Clin Pathol 2001, 115: 194-204

25. Elder DE: Precursors to melanoma and their mimics: nevi of special sites. Mod Pathol 2006, 19: 4-20

26. Shea CR, Vollmer RT, Prieto VG: Correlating architectural disorder and cytologic atypia in Clark (dysplastic) melanocytic nevi. Hum Pathol 1999, 30: 500-505

27. Küpelioğlu AA, Pabuç̧uoğlu HU: Patoloji ve Sitopatoloji Laboratuvar Teknikleri. 1. baskı, İzmir, Dokuz Eylül Üniversitesi, 1995, 89-90

28. Shors AR, Kim S, White E, Argenyi Z, Barnhill RL, Duray P, Erickson L, Guitart J, Horenstein MG, Lowe L, Messina J, Rabkin MS, Schmidt B, Shea CR, Trotter MJ, Piepkorn MW: Dysplastic naevi with moderate to severe histological dysplasia: a risk factor for melanoma. Br J Dermatol 2006, 155: 988-993

29. Weinstock MA, Barnhill RL, Rhodes AR, Brodsky GL: Reliability of the histopathologic diagnosis of melanocytic dysplasia. The Dysplastic Nevus Panel. Arch Dermatol 1997, 133: 953-958

30. Smoller BR, Egbert BM: Dysplastic nevi can be diagnosed and graded reproducibly: a longitudinal study. J Am Acad Dermatol 1992, 27: 399-402

31. Barnhill RL, Roush GC, Duray PH: Correlation of histologic architectural and cytoplasmic features with nuclear atypia in atypical (dysplastic) nevomelanocytic nevi. Hum Pathol 1990, 21: 51-58

32. Balkau D, Gartmann H, Wischer W, Grootens A, Hagemeier HH, Hundeiker M, Suter L: Architectural features in melanocytic lesions with cellular atypia. Dermatologica 1988, 177: 129-137

33. Culpepper KS, Granter SR, McKee PH: My approach to atypical melanocytic lesions. J Clin Pathol 2004, 57: 1121-1131

34. Friedman RJ, Farber MJ, Warycha MA, Papathasis N, Miller MK, Heilman ER: The "dysplastic" nevus. Clin Dermatol 2009, 27: 103-115

35. Schaumburg-Lever G, Lever I, Fehrenbacher B, Möller H, Bischof B, Kaiserling E, Garbe C, Rassner G: Melanocytes in nevi and melanomas synthesize basement membrane and basement membrane-like material. An immunohistochemical and electron microscopic study including immunoelectron microscopy. J Cutan Pathol 2000, 27: 67-75

36. Giehl KA, Nägele U, Volkenandt M, Berking C: Protein expression of melanocyte growth factors (bFGF, SCF) and their receptors (FGFR-1, c-kit) in nevi and melanoma. J Cutan Pathol 2007, 34: 7-14

37. Clark WH Jr, Hood AF, Tucker MA, Jampel RM: Atypical melanocytic nevi of the genital type with a discussion of reciprocal parenchymal-stromal interactions in the biology of neoplasia. Hum Pathol 1998, 29: 1-24 